\title{
Unlocking the potential of tropical root crop biotechnology in east Africa by establishing a genetic transformation platform for local farmer-preferred cassava cultivars
}

\section{Evans Nyaboga ${ }^{1,2,3}$, Joshua Njiru ${ }^{1}$, Edward $\mathrm{Nguu}^{3}$, Wilhelm Gruissem ${ }^{2}$, Herve Vanderschuren ${ }^{2}$ and Leena Tripathi ${ }^{1 *}$}

1 International Institute of Tropical Agriculture, Nairobi, Kenya

2 Department of Biology, Plant Biotechnology, Eidgenössische Technische Hochschule, Zurich, Switzerland

${ }^{3}$ Department of Biochemistry, University of Nairobi, Nairobi, Kenya

\section{Edited by:}

Martin Weih, Swedish University of Agricultural Sciences (SLU), Sweden

Reviewed by:

Birgit M. Draeger, Martin Luther

University, Germany

Peng Zhang, Chinese Academy of

Science, China

*Correspondence:

Leena Tripathi, International Institute of Tropical Agriculture, C/O

International Livestock Research Institute, PO Box 30709-00100

Nairobi, Kenya

e-mail: I.tripathi@cgiar.org
Cassava genetic transformation capacity is still mostly restricted to advanced laboratories in the USA, Europe and China; and its implementation and maintenance in African laboratories has remained scarce. The impact of transgenic technologies for genetic improvement of cassava will depend largely on the transfer of such capabilities to researchers in Africa, where cassava has an important socioeconomic niche. A major constraint to the development of genetic transformation technologies for cassava improvement has been the lack of an efficient and robust transformation and regeneration system. Despite the success achieved in genetic modification of few cassava cultivars, including the model cultivar 60444, transgenic cassava production remains difficult for farmer-preferred cultivars. In this study, a protocol for cultivar 60444 developed at ETH Zurich was successfully implemented and optimized to establish transformation of farmer-preferred cassava cultivars popular in east Africa. The conditions for production and proliferation of friable embryogenic calli (FEC) and Agrobacterium-mediated transformation were optimized for three east African farmer-preferred cultivars (Ebwanatereka, Kibandameno and Serere). Our results demonstrated transformation efficiencies of about 14-22 independent transgenic lines per $100 \mathrm{mg}$ of FEC for farmer-preferred cultivars in comparison to 28 lines per $100 \mathrm{mg}$ of the model cultivar 60444. The presence, integration and expression of the transgenes were confirmed by PCR, Southern blot analysis and histochemical GUS assay. This study reports the establishment of a cassava transformation platform at International Institute of Tropical Agriculture (IITA) hosted by Biosciences eastern and central Africa (BecA) hub in Kenya and provides the basis for transferring important traits such as virus resistance and prolonged shelf-life to farmerpreferred cultivars in east Africa. We anticipate that such platform will also be instrumental to transfer technologies to national agricultural research systems (NARS) in sub-Saharan Africa.

Keywords: cassava, friable embryogenic callus, Agrobacterium tumefaciens, genetic transformation, farmer-preferred cultivars

\section{INTRODUCTION}

Cassava (Manihot esculenta Crantz) is the third most important source of calories in the tropics, after rice and maize (FAOSTAT, 2008). Millions of people depend on cassava in Africa, Asia and Latin America. It is vital for food security as well as income generation for farmers including poor farmers, many of them women, growing cassava on marginal land. Global production of cassava is about 256 Million tonnes, out of which 146 Million tonnes are produced in Africa (FAOSTAT, 2012). The global demand for cassava is rapidly growing because of its increasing use by the starch industry and its good potential for biofuel production (Jansson et al., 2009). Despite its importance there are traits that need improvement, such as pest and disease susceptibilities, accumulation of cyanogens, and post-harvest physiological deterioration (Ceballos et al., 2004; Sayre et al., 2011). Due to the high heterozygosity, allopolyploidy, low fertility as well as unsynchronized flowering of cassava, conventional breeding is difficult and time-consuming (Ceballos et al., 2004). As an alternative, genetic transformation offers great potential for cassava improvement (Liu et al., 2011).

The ability to use biotechnological tools to improve cassava was proved possible in the mid 1990s. Li et al. (1996) reported Agrobacterium-mediated transformation of somatic cotyledons to regenerate transgenic shoots by organogenesis. Simultaneously, Schöpke et al. (1996), demonstrated regeneration of transgenic plantlets through microparticle bombardment of embryogenic cell suspensions. In the latter system, transformation relied on the generation of embryogenic cell clusters, known as friable 
embryogenic callus (FEC) as the target material for transformation. However, some of the disadvantages of microprojectile bombardment are that the transformation efficiency may be lower than with Agrobacterium-mediated transformation and the device and consumables are costly. Also Agrobacterium-mediated transformation offers several other advantages over microprojectile bombardment procedure, such as the possibility to transfer only one or few copies of DNA fragments carrying the genes of interest at higher efficiencies with lower cost and the transfer of very large DNA fragments with minimal rearrangement (Shibata and Liu, 2000; Gelvin, 2003). Therefore, plant transformation through Agrobacterium-mediated DNA transfer has become a favored approach for many crop species (Barampuram and Zhang, 2011). For the generation of transgenic cassava, Agrobacterium-mediated transformation of FEC, a combination of the two original systems, has become the most efficient and preferred strategy (Liu et al., 2011).

The FECs are preferred tissue for transformation as it reduces the risk of generating chimeric plants compared to procedures using organized tissues, such as cotyledons (González et al., 1998). Protocols using FEC also appeared suitable for large production of independent transgenic events particularly with the model cultivar 60444 (Bull et al., 2009). However, despite the original techniques being published approximately 18 years ago, the uptake and success rate by different laboratories has been poor, particularly in sub-Saharan Africa, where cassava is an important staple crop. The lack of uptake of the technology in Africa has been largely attributed to the limited number of well equipped laboratories and technique(s) being complicated and labor-intensive, but also the difficulty in adapting the protocols developed for the model cultivar 60444 with farmerpreferred cultivars. Long-term success of transgenic technologies for genetic improvement of cassava will depend largely on the transfer and expansion of such capabilities to researchers in Africa, where these systems can be exploited for specific local needs in the relevant germplasm (Machuka, 2001; Toennissen et al., 2003; Vanderschuren, 2012).

Although a tropical crop, the technical expertise required to develop and apply genetic transformation technology in cassava is still mostly restricted to advanced laboratories; and its implementation and maintenance in laboratories in developing countries has remained scarce. A critical issue for the successful adoption of transgenic cassava by farmers in Africa is establishment of well equipped laboratories and the development of human resource capacity to produce transgenic cassava using farmer-preferred cultivars with important agronomic traits (Ezezika et al., 2012). Hundreds of genetically distinct varieties of the crop are known to exist, however, only a very small fraction of these will ever be targeted within genetic engineering programs. Therefore, there is a need to develop capacities to transform the most important local cultivars and landraces (Taylor et al., 2002). Because transgenic strategies to improve cassava now being evaluated in the field (Zhang et al., 2010; Koehorst-van Putten et al., 2012; Ogwok et al., 2012) are so far restricted to two cultivars, it is also important to assess the technology in cassava genotypes adapted to the respective field environments. Locally adapted cultivars and landraces have often been selected and adopted by farmers because of particular improved traits (Kawuki et al., 2011). Therefore, transgenic programs must generate products readily acceptable to the intended end users.

To date, effective FEC-based transformation protocols have been developed mainly for cultivar 60444, which is considered as a model African cassava cultivar (Bull et al., 2009; Taylor et al., 2012). Although this cultivar could be used for research purposes, it is not anymore cultivated by farmers because of low yield, low nutritional quality and susceptibility to viral and bacterial diseases. Previous studies using the FEC-based cassava transformation method reported the introduction of important agronomic traits, such as resistance to African cassava mosaic virus (ACMV) and cassava brown streak virus (CBSV) in cultivars 60444 and TME7 (Zhang et al., 2005; Vanderschuren et al., 2009, 2012; Yadav et al., 2011). A procedure to transform landraces from the TME series has been recently developed (Zainuddin et al., 2012) at ETH Zurich and also used successfully to transform the industry-preferred cultivar T200 in South Africa (Chetty et al., 2013). However, transformation of cassava cultivars particularly preferred by African farmers remains challenging because FEC production tends to be genotype-dependent and regeneration of transformed FEC is often problematic (Raemakers et al., 2001; Chetty et al., 2013).

Here we report the successful implementation of a robust cassava transformation platform at IITA hosted by BecA hub in Nairobi and its use for the generation of transgenic cassava of local farmer-preferred cultivars selected based on their economic importance, frequency of cultivation in different geographical and climatic zones of east Africa, and susceptibility to major production constraints in sub-Saharan Africa.

\section{MATERIALS AND METHODS CASSAVA MATERIAL}

Cassava cultivars (Ebwanatereka and Serere) were obtained from Kenya Agricultural Research Institute (KARI), Kenya and cultivar 60444 was obtained from ETH, Zurich. The cultivars Mkombozi, Kibandameno, Albert, Kibaha and TME14 were obtained from germplasm collection at IITA. All the cultivars were maintained as shoot cultures on cassava basic medium (CBM; Supplementary Table 1 ) at $28^{\circ} \mathrm{C}$ under a $16 / 8 \mathrm{~h}$ photoperiod (Figure 1A).

\section{SOMATIC EMBRYOGENESIS}

Nodal explants were cut and placed horizontally on cassava axillary bud medium (CAM; Supplementary Table 1) for 3-6 days, depending on the cultivar used. The enlarged axillary buds (AB; Figure 1B) were removed from the nodal explants with a sterile hypodermic needle and transferred onto embryo induction medium (CIM; Supplementary Table 1). For immature leaf lobe (ILL), 2-6 mm length explants were excised from in vitro mother plantlets and placed on CIM. Organized embryogenic structures (OES) were induced from axillary buds $(\mathrm{AB})$ and immature leaf lobe (ILL) explants, according to procedure previously described (Bull et al., 2009; Taylor et al., 2012). A hundred and forty explants were used in each experiment. Explants were incubated for 4 weeks at $28^{\circ} \mathrm{C}$ in the dark and subculturing at 14 days. The comparative potential of somatic embryogenesis was evaluated 

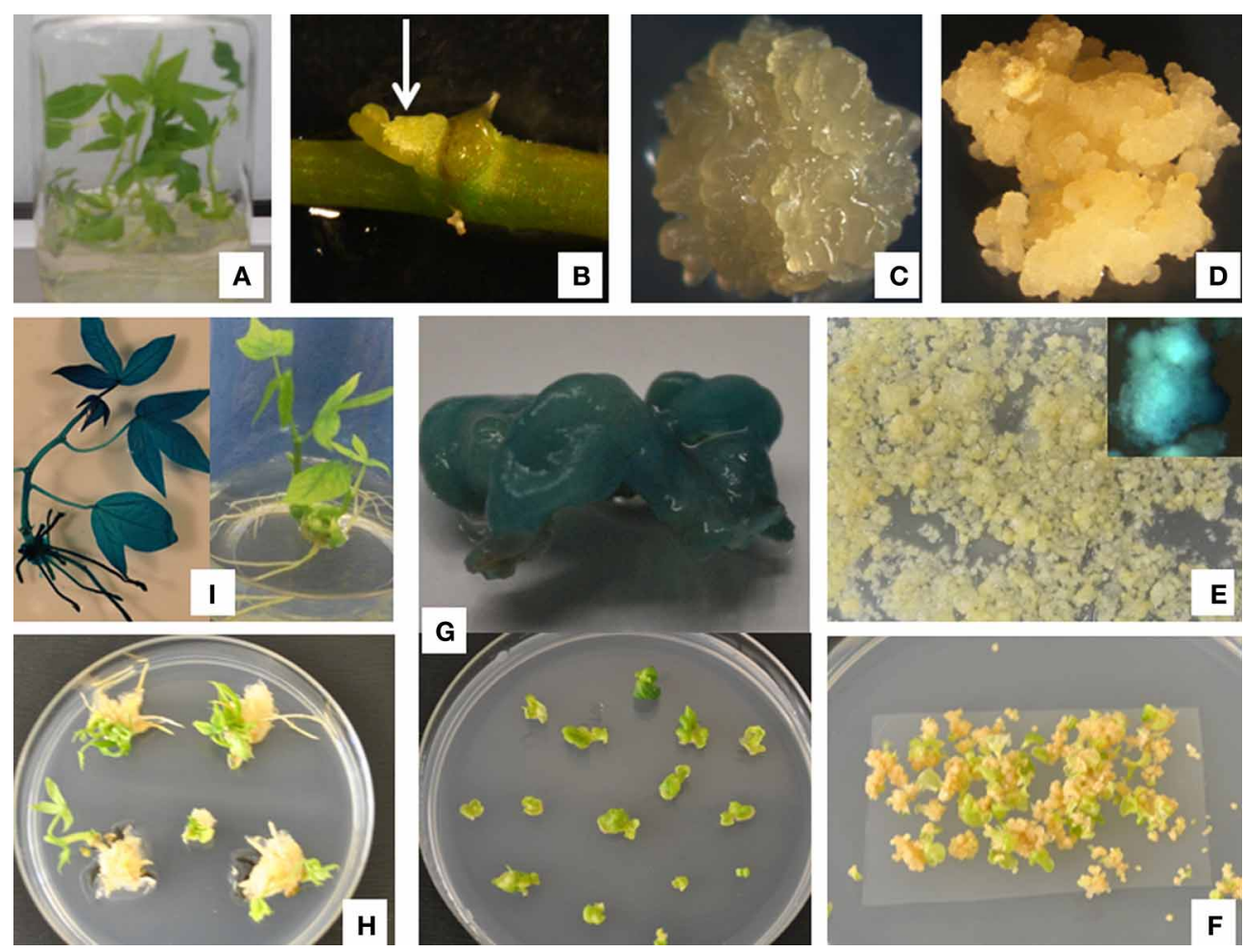

FIGURE 1 | Agrobacterium-mediated transformation of cassava cultivar Serere using FEC. (A) In vitro shoot culture; (B) axillary bud (arrow); (C) primary somatic embryos; (D) friable embryogenic callus; (E) Agrobacterium-inoculated FEC proliferating on selective medium and transient GUS assay (upper right corner); (F) somatic embryos/cotyledons on selective embryo development and maturation medium; (G) mature somatic embryos on shoot elongation medium and GUS positive somatic embryos (up); (H) shoots developing on shoot elongation medium; (I) transgenic plantlets germinated on basic cassava medium and GUS expression in shoot (left). based on the frequency ( $x / 140$ explants) of OES production for each cultivar.

\section{PRODUCTION AND MAINTENANCE OF FRIABLE EMBRYOGENIC CALLUS (FEC)}

Production of FEC was performed according to the protocols described by Bull et al. (2009) with modifications. Primary organized embryogenic clusters were transferred to Greshoff and Doy (GD) medium (Gresshoff and Doy, 1974; Supplementary Table 1) supplemented with $50 \mu \mathrm{M}$ of picloram and incubated at $28^{\circ} \mathrm{C}$ in dark. FECs were subsequently grown under $16 / 8 \mathrm{~h}$ photoperiod and $28^{\circ} \mathrm{C}$ conditions and sub-cultured onto fresh media every 3 weeks. The effect of L-tyrosine on FEC production in cassava cultivars was evaluated by transferring OES onto GD medium supplemented with $50 \mu \mathrm{M}$ picloram in combination with different concentrations of tyrosine $(125,250$, and $500 \mu \mathrm{M})$.

\section{REGENERATION OF FECS}

Assessment of the FEC regeneration potential was performed with $50 \mathrm{mg}$ of FEC tissues spread on mesh and cultured on embryo maturation and germination media (MSN; Supplementary Table 1 ) at $28^{\circ} \mathrm{C}$ under $16 / 8 \mathrm{~h}$ photoperiod. The emerging green cotyledons were counted, removed and placed on cassava shoot elongation medium (CEM;
Supplementary Table 1), while the remaining FECs were transferred to fresh media every 10 days. The regeneration capacity was measured as the total number of green cotyledons produced over 100 days. Germinating shoots were transferred to cassava basic medium (CBM, Supplementary Table 1) for establishment of plantlets. The regeneration process was monitored as the total number of green cotyledons produced within 100 days and the total number of plants regenerated.

\section{Agrobacterium AND BINARY VECTORS}

Agrobacterium tumefaciens strain LBA4404 carrying the binary vector pCAMBIA1301 was used in this study. The pCAMBIA1301 (GenBank AF234297) contains hygromycin phosphotransferase gene $(h p t)$ as selection marker and $\beta$-glucuronidase (gusA) reporter gene with a plant intron, both driven by the constitutive Cauliflower mosaic virus promoter (CAMV 35S) (Supplementary Figure 1). The binary vector was transformed into Agrobacterium tumefaciens strain LBA4404 by electroporation. Single colonies from LB agar plates containing kanamycin $\left(50 \mathrm{mg} \mathrm{l}^{-1}\right)$, rifampicin $\left(50 \mathrm{mg}^{-1}\right)$ and streptomycin (100 mg $1^{-1}$ ) were used to initiate $2 \mathrm{ml} \mathrm{LB}$ medium as starter cultures. After $48 \mathrm{~h}$ shaking at $150 \mathrm{rpm}$ at $28^{\circ} \mathrm{C}$, this suspension was used to inoculate a $20 \mathrm{ml}$ YEP medium containing the same antibiotics, and grown overnight on a shaking platform at $150 \mathrm{rpm}$ to reach an $\mathrm{OD}_{600}$ of $0.75-1.0$. Bacteria were spun down and washed twice 
with liquid GD medium. The pellet of bacteria was re-suspended in liquid GD medium supplemented with $200 \mu \mathrm{M}$ acetosyringone (Sigma Chemical Co.) to an $\mathrm{OD}_{600}$ of 0.5 .

\section{TRANSFORMATION, SELECTION AND REGENERATION OF TRANSGENIC PLANTS}

Three month old FECs $(100 \mathrm{mg}$ ) were co-cultivated with $10 \mathrm{ml}$ of the Agrobacterium tumefaciens strain harboring pCAMBIA1301 in sterile $50 \mathrm{ml}$ falcon tubes, mixed vigorously to disaggregate the callus tissues and incubated for $30 \mathrm{~min}$ with gentle shaking (40 rpm). Agro-inoculated FEC tissues were transferred onto a $100 \mu \mathrm{m}$ mesh placed on sterilized paper towel for $5 \mathrm{~min}$ to remove excess bacteria. The FEC were co-cultivated on GD medium for 3 days with Agrobacterium under light (16/8 h photoperiod) at $22^{\circ} \mathrm{C}$. Following the co-cultivation step, Agro-inoculated FEC were washed 3 times with liquid GD medium containing $500 \mathrm{mg} \mathrm{l}^{-1}$ carbenicillin and transferred to mesh. The mesh was placed on GD media supplemented with $250 \mathrm{mg} \mathrm{l}^{-1}$ carbenicillin and incubated for 4 days of recovery at $28^{\circ} \mathrm{C} 16 / 8 \mathrm{~h}$ photoperiod. After 4 days of incubation, the mesh was transferred to fresh GD medium supplemented with $250 \mathrm{mg} \mathrm{l}^{-1}$ carbenicillin and $5 \mathrm{mg} \mathrm{l}^{-1}$ hygromycin and kept under $16 / 8 \mathrm{~h}$ photoperiod at $28^{\circ} \mathrm{C}$ for 7 days. This step was repeated twice with gradually increasing the hygromycin selection to 8 and $15 \mathrm{mg} \mathrm{l}^{-1}$. Following the FEC selection on GD media, the mesh with FEC was transferred to MSN medium supplemented with $250 \mathrm{mg}$ $\mathrm{l}^{-1}$ carbenicillin and $15 \mathrm{mg} \mathrm{l}^{-1}$ hygromycin and kept under $16 / 8 \mathrm{~h}$ photoperiod at $28^{\circ} \mathrm{C}$ with fortnightly subculturing on fresh MSN medium.

Matured embryos developing cotyledons on selective MSN medium were transferred to CEM supplemented with $100 \mathrm{mg}$ $1^{-1}$ carbenicillin with fortnightly subculturing onto fresh CEM medium for cotyledon development and shoot elongation. The elongated shoots were transferred to CBM for rooting. Rooted plantlets were screened for escapes by transferring stem cuttings to CBM supplemented with carbenicilin $50 \mathrm{mg} \mathrm{l}^{-1}$ and hygromycin $10 \mathrm{mg} \mathrm{l}^{-1}$ as previously described (Bull et al., 2009). Rooting of the plantlets on selective media was recorded after 2-3 weeks.

The well rooted plantlets were transferred to plastic pots $(10 \mathrm{~cm}$ diameter) containing sterile coconut peat. Pots were placed in trays and covered with a transparent cover and placed in a glasshouse at $28^{\circ} \mathrm{C}$. The cover was opened partially after a week and removed after 2 weeks. The hardened plantlets $(10 \mathrm{~cm}$ in height) were transferred into bigger plastic pots $(30 \times 40 \mathrm{~cm})$ for further development of tuberous roots and growth monitoring under glasshouse conditions.

\section{HISTOCHEMICAL GUS ASSAYS}

Histochemical GUS assays for transient gene expression was performed 3 days after co-cultivation according to the modified procedure of Jefferson (1987) as described by Bull et al. (2009) for cassava. Transient GUS expression frequencies were determined by expressing GUS positive calli as a proportion (\%) of the total number of calli in the sample. Stable GUS expression was checked using callus, cotyledonary stage embryos and hygromycin-resistant regenerated plants.

\section{MOLECULAR ANALYSIS OF TRANSGENIC LINES}

Both PCR and Southern blot analyses were carried out to confirm the transformation events. The total genomic DNA was extracted from in vitro grown shoots using the cetyltrimethylammonium bromide (CTAB) method (Soni and Murray, 1994). For PCR analysis the hpt and gusA genes were amplified to confirm the integration of the transgene. The primer sequences were forward primer 5' $5^{\prime}$-AAAGTGTGGGTCAATAATCAGG-3' ${ }^{\prime}$ and reverse primer $5^{\prime}$-ATGGATTCCGGCATAGTTAAAG-3' designed to amplify a $215 \mathrm{bp}$ fragment from the gusA gene; forward primer $5^{\prime}$-GATGTTGGCGACCTCGT-3' and reverse primer $5^{\prime}$ GTGTCACGTTGCAAGACCTG-3' amplifying a 415 bp fragment from the $h p t$ gene.

For Southern blot hybridization $15 \mu \mathrm{g}$ of DNA was digested with $3 \mathrm{U} \mu \mathrm{g}^{-1}$ HindIII (New England Biolabs Inc. MA, USA) overnight at $37^{\circ} \mathrm{C}$ and resolved on $0.8 \%$ agarose gels. DNA was blotted onto Hybond-N+ nylon membrane (Roche) and fixed by cross-linking in a STRATA-LINK ${ }^{\mathrm{TM}}$ UV cross-linker. The blots were hybridized with digoxigenin (DIG)-labeled gusA-specific probe generated using a PCR DIG Probe Synthesis Kit (Roche Applied Sciences, Mannheim, Germany). Hybridization and detection were carried out using a DIG Luminescent Detection Kit for Nucleic Acids (Roche Applied Sciences, Mannheim, Germany), according to the manufacturer's instructions.

\section{DATA ANALYSIS}

All the experiments were repeated three times and data for all parameters were analyzed by analysis of variance (ANOVA) using PROC ANOVA of SAS 9.2 (SAS Institute, Cary, NC), and Duncan's new multiple range test was used to detect significant differences between means.

\section{RESULTS AND DISCUSSION SELECTION OF ACCESSIONS PREFERRED IN EAST AFRICA}

The identification of cassava cultivars that will be readily adopted by significant numbers of farmers in sub-Saharan Africa is essential for the development of genetically modified (GM) product. Resource poor farmers prefer cultivars that offer several important traits like cooking quality, time to maturity, yield and disease resistance. The local cultivars preferred in east Africa (Serere, Ebwanatereka, Kibandameno, Mkombozi, Kibaha, Albert and TME14) were selected, based on consultation with cassava breeders, for establishment of genetic transformation system. These cultivars were selected due to their economic importance and wide cultivation across several countries in east Africa (Table 1). The selected cultivars are high-yielding and have desirable root quality attributes such as taste, mealiness, texture, aroma, flavor, cooking qualities and market value (National Cassava Programme-Uganda Report, 2005). However, all these cultivars are highly susceptible to both CMD and cassava brown streak disease (CBSD) except TME14, which is only susceptible to CBSD (Ntawuruhunga and Legg, 2007). All these cultivars are also highly susceptible to cassava bacterial blight (CBB) and postharvest physiological deterioration (PPD). Resistance to CMD, $\mathrm{CBSD}, \mathrm{CBB}$ as well as prolonged shelf life is therefore considered as priority traits for these cultivars. The aforementioned cultivars with improved traits would certainly be perceived favorably 
Table 1 | Origin, agronomic traits and tuber quality attributes of selected cassava cultivars and landraces preferred in east Africa.

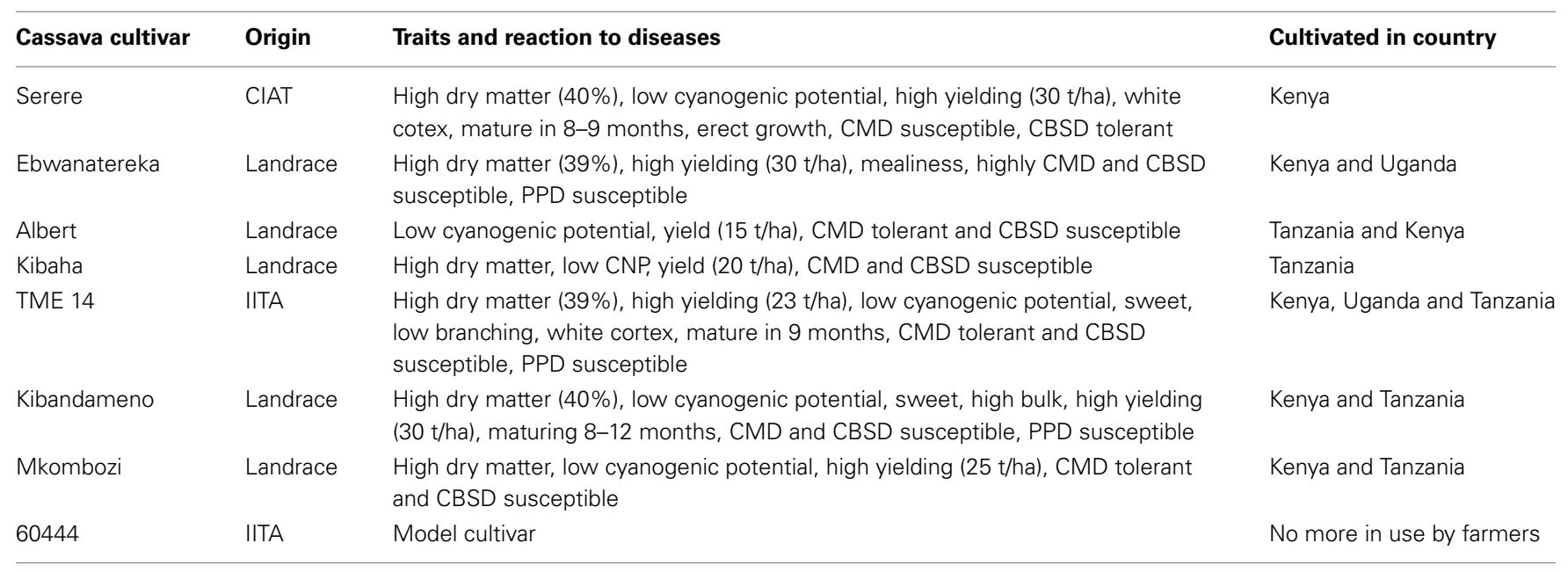

and adopted, if available, by small landholder farmers in east Africa.

\section{PRODUCTION OF FEC OF FARMER-PREFERRED CULTIVARS}

Successful genetic transformation of cassava using FECs depends initially on the production of OES, and the ability of OES to induce and proliferate into pure and homogeneous FEC (Taylor et al., 2004; Liu et al., 2011). In this study, high quality OES were obtained from both $\mathrm{AB}$ and ILL explants of all cassava cultivars tested. OES induction efficiencies ranged from 65 to $86 \%$ for $\mathrm{AB}$ explants and $62-85 \%$ for ILL explants (Table 2). Depending on the cultivar, the formation of OES was observed on $\mathrm{AB}$ and ILL explants after 10-14 and 18-28 days, respectively. The highest frequencies of somatic embryogenesis for cultivars 60444, Ebwanatereka and Kibandameno were obtained using AB explants (Table 2). The cultivar Serere performed equally well using $\mathrm{AB}$ and ILL explants producing OES frequencies of 84 and $85 \%$, respectively (Table 2; Figure 1C). The induction of primary embryogenic tissues from the explant is considered to be the most important step during the production of target tissues for gene insertion in cassava. Failure to establish efficient procedures for this step, in order to eventually produce FEC tissues, renders cassava genetic transformation impossible. In this study, we demonstrated, for the first time, OES production in farmer-preferred cultivars of cassava using two different types of explants.

The generation and propagation of FEC is fundamental for successful and efficient transformation. Protocols for generation of FEC have been lacking for east African cassava cultivars, thereby delaying their genetic engineering for agronomic and other desirable traits. Work at IITA-Nairobi in collaboration with ETH Zurich led to optimizing conditions suitable for production and regeneration of FEC from the selected cassava cultivars. FEC were obtained for three local cultivars (Ebwanatereka, Serere and Kibandameno) in addition to model cultivar 60444 (Figure 1D), whereas the other four local cultivars (Mkombozi, Albert, Kibaha and TME14) did not produce any FEC. Our results suggests that FEC production is cultivar-dependent and it is possible that
Table 2 | Average frequencies of somatic embryos induced from different explants of various cassava cultivars.

\begin{tabular}{lll}
\hline Cassava cultivar & \multicolumn{2}{c}{ OES production frequency (\%) } \\
\cline { 2 - 3 } & $\begin{array}{l}\text { Axillary buds } \\
\text { (AB) }\end{array}$ & $\begin{array}{l}\text { Immature leaf lobes } \\
\text { (ILL) }\end{array}$ \\
\hline 60444 & $86.19 \pm 6.07$ & $73.57 \pm 11.09$ \\
Ebwanatereka & $80.95 \pm 3.22$ & $74.29 \pm 8.24$ \\
Serere & $84.29 \pm 9.37$ & $85.48 \pm 2.89$ \\
Kibandameno & $83.39 \pm 8.23$ & $70.24 \pm 3.84$ \\
Mkombozi & $81.79 \pm 7.57$ & $64.36 \pm 9.37$ \\
Kibaha & $69.52 \pm 10.21$ & $62.86 \pm 9.29$ \\
Albert & $65.71 \pm 7.73$ & $70.24 \pm 10.53$ \\
TME14 & $78.57 \pm 7.25$ & $65.71 \pm 8.95$ \\
\hline
\end{tabular}

*Percentage OES produced from 140 explants; OES production frequencies were recorded by calculating the ratio of OES clusters/cultured explants. Data represents means $\pm S D$ of three independent experiments.

Mkombozi, Albert, Kibaha and TME14 need further optimization of tissue culture conditions, media composition and timing to produce FEC. Supplementation of L-tyrosine at $250 \mu \mathrm{M}$ into FEC induction medium significantly enhanced OES conversion into FEC in three cultivars (Ebwanatereka, Serere and 60444) where as FEC production and proliferation were impeded on L-tyrosinebased media for Kibandameno (Figure 2), suggesting that the L-tyrosine effect is also genotype-dependent. The increase of 1.7-7.2 fold in FEC production was recorded for Ebwanatereka and Serere, respectively, when OES were placed on GD medium supplemented with $250 \mu \mathrm{M}$ L-tyrosine.

The genotypic effect on FEC production of cassava genotypes tested in this study was also observed in the FEC production of a range of Asian cassava genotypes (Raemakers et al., 2001) and recognized as one of the major limitations of the application of FEC in genetic transformation of farmer-preferred cultivars of cassava (Taylor et al., 1997; Fregene and Puonti-Kaerlas, 2002; Hankoua et al., 2005; Liu et al., 2011). These observations demonstrate that there might be an underlying genetic control in the 
capability of a given genotype to induce and proliferate FECs. The time required to generate FEC from OES also varied between cultivars, ranging from 9 to 22 weeks. Kibandameno was similar to cultivar 60444 and initiated FEC production within 9-11 weeks. Formation of FEC from cultivar Serere was also relatively rapid (12 weeks), whereas Ebwanatereka took 18-22 weeks to form FEC. Depending on the cultivar, 3-6 subcultures of 21 days each resulted in rapidly proliferating, pale yellow FECs. Such variations in time required to obtain FEC cultures imply that cultures should be screened for sufficient periods of time before any conclusion on the response of a cultivar is made.

Since genetic transformation system depend on regeneration of transformed FEC tissue and each cassava cultivar may not respond in those reported condition, we evaluated the regenerative potential of FEC of the three farmer-preferred cultivars (Serere, Ebwanatereka and Kibandameno) and compared with cultivar 60444. The regeneration potential of FEC from these cultivars is presented in Table 3. All the cultivars tested were highly regenerative, producing an average of over 40 cotyledonstage embryos per $50 \mathrm{mg}$ of FEC (Table 3). More cotyledon-stage embryos were produced from FECs of Serere in comparison to cultivar 60444 . In total 54, 50, 40, and 37 cotyledon-stage embryos were produced from Serere, 60444, Ebwanatereka and

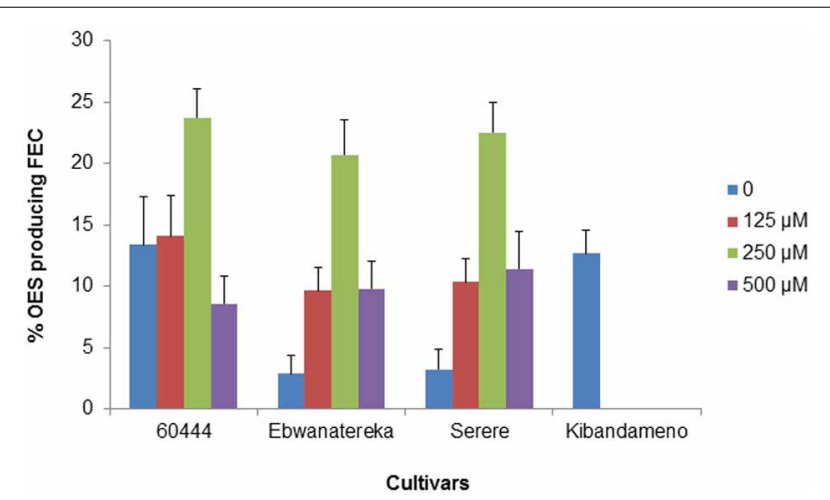

FIGURE 2 | Effect of L-tyrosine on the production of FEC from different cassava cultivars. FEC production frequencies were recorded by calculating the ratio of FEC clusters/OES cultured. Values are means $\pm S D$ of three independent experiments.

Table 3 | Regeneration of complete plants from FECs of four cultivars of cassava.

\begin{tabular}{|c|c|c|c|}
\hline $\begin{array}{l}\text { Cassava } \\
\text { cultivar }\end{array}$ & $\begin{array}{l}\text { Cotyledonary- } \\
\text { stage embryos } \\
\text { recovered per } \\
50 \mathrm{mg} \text { FEC }\end{array}$ & $\begin{array}{l}\text { Average } \\
\text { germination of } \\
\text { cotyledonary- } \\
\text { stage embryos } \\
(\%)\end{array}$ & $\begin{array}{l}\text { Plants } \\
\text { regenerated } \\
\text { per } 50 \mathrm{mg} \\
\text { FEC }\end{array}$ \\
\hline 60444 & $50.75 \pm 5.90^{b}$ & $52.17 \pm 4.55^{c}$ & $17.75 \pm 5.56$ \\
\hline Serere & $54.75 \pm 3.80^{c}$ & $54.13 \pm 6.44^{c}$ & $24.5 \pm 5.26$ \\
\hline Ebwanatereka & $40 \pm 11.81^{a}$ & $47.29 \pm 3.88^{b}$ & $16.5 \pm 6.44$ \\
\hline Kibandameno & $37 \pm 8.44^{a}$ & $44.32 \pm 5.64^{a}$ & $14.5 \pm 4.48$ \\
\hline
\end{tabular}

Values are means $\pm S D$ of three independent experiments. Values in a column followed by different letters are significantly different from each other at $p \leq 0.05$.
Kibanadameno, respectively, over 100 days (Table 3). There was no significant difference $(p \leq 0.05)$ in germination of cotyledonstage embryos of Serere in comparison to cultivar 60444, whereas germination of cotyledon-stage embryos of Ebwanatereka and Kibandameno was significantly $(p \leq 0.05)$ lower. The differences in regeneration efficiencies would be due to genotypic differences. The relatively high germination frequencies of FECs from Serere, Ebwanatereka, Kibandameno and cultivar 60444 suggested that FEC tissues produced from these cultivars could be suitable for genetic transformation. It was, however, noted that not all somatic embryos produced plantlets showing poor correlation between capacity to form somatic embryos and plant regeneration.

\section{ESTABLISHMENT OF TRANSFORMATION METHOD FOR FARMER-PREFERRED CULTIVARS}

In this study, we demonstrated successful and reproducible transformation and regeneration system for three local farmer-preferred cassava cultivars (Serere, Ebwanateraka and Kibandameno) commonly grown in east Africa, using the modified protocol of Bull et al. (2009). Transformation and regeneration of cultivar 60444 required minimal trouble shooting, provided that the experimental parameters were kept as close as possible to those stipulated in the protocol described by Bull et al. (2009) whereas modifications of the protocol such as supplementation of L-tyrosine were required to generate FEC and establish the transformation of some of the local farmer-preferred cultivars. Central to success with this system is the production of sufficient quantity of quality FECs as target tissues for genetic transformation.

Previously, Agro-inoculation was done by dropping Agrobacterium liquid suspension directly to FEC clusters on the propagation solid medium (Bull et al., 2009). However, in this study, Agro-inoculation was modified by immersing FEC in Agrobacterium cell suspension for $30 \mathrm{~min}$ at room temperature with gentle shaking at $40 \mathrm{rpm}$. This allowed efficient Agrobacterium contact on FEC cells for subsequent infection process as reported in other crops such as banana (Tripathi et al., 2012). Following co-inoculation with Agrobacterium transformed FECs proliferated into small clusters of pale yellow colored calli on hygromycin selection media (Figure 1E). Clusters of transformed FECs started developing into somatic embryos after transfer to MSN media (Figure 1F). After seven cycles of 10 days each on MSN, about 140-240 putatively transformed somatic embryos were produced depending upon cultivars (Table 4). Somatic embryos from the aforementioned cultivars maturing on selective MSN media were transferred to elongation media (CEM), where about $26-45 \%$ somatic embryos germinated (Figures 1G,H; Table 4). Serere performed significantly $(p \leq 0.05)$ better in comparison to model cultivar 60444 at this stage of regeneration of transformants, whereas Ebwanatereka and Kibandameno had a significantly $(p \leq 0.05)$ lower efficiency of somatic embryo germination (Table 4). Germination of somatic embryos is accompanied by the activation in expression of myriad of genes encoding photosynthetic and chloroplast components (Baba et al., 2008). Time differences in activation of these genes might have caused variation in germination 
Table 4 | Regeneration and validation of transgenic plants of various cultivars of cassava using FECs*.

\begin{tabular}{llllll}
\hline Cassava cultivar & $\begin{array}{l}\text { Percentage cell cluster showing } \\
\text { transient GUS expression }\end{array}$ & $\begin{array}{l}\text { No. of somatic } \\
\text { embryos on selection }\end{array}$ & $\begin{array}{l}\text { Germinated } \\
\text { embryos (\%) }\end{array}$ & $\begin{array}{l}\text { Regenerated } \\
\text { plants }^{\boldsymbol{d}}\end{array}$ \\
\hline 60444 & 61.38 & $202^{\mathrm{c}}$ & $36.6^{\mathrm{c}}$ & $28(37.8 \%)^{\mathrm{c}}$ & 100 \\
Serere & 53.51 & $240^{\mathrm{d}}$ & $45.0^{\mathrm{d}}$ & $22(20.4 \%)^{\mathrm{b}}$ & 100 \\
Ebwanatereka & 46.15 & $187^{\mathrm{b}}$ & $25.7^{\mathrm{a}}$ & $17(35.4 \%)^{\mathrm{a}}$ & 100 \\
Kibandameno & 51.20 & $141^{\mathrm{a}}$ & $30.5^{\mathrm{b}}$ & $14(32.6 \%)^{\mathrm{a}}$ & 100 \\
\hline
\end{tabular}

${ }^{*} 100 \mathrm{mg}$ of FEC for each cultivar was used in each experiment; $\$$ Percentage with respect to germinated embryos. Values in a column followed by different letters are significantly different from each other at $p \leq 0.05$.

of somatic embryos derived from the different local cassava cultivars. Transgenic lines were regenerated in a 3-5 month period after Agro-inoculation of FECs of cultivar 60444, Serere, Ebwanatereka and Kibandameno (Table 4; Figure 1I). Previous studies together with our findings suggest that, the regeneration of plants from cassava somatic embryos is a challenging task, especially due to the low frequency of embryo germination, and this caveat has prevented the generation of transgenic cassava from a wider range of genotypes. Transformation frequency of the model cultivar 60444 was slightly higher than Serere, Ebwanatereka and Kibandameno. We obtained about 22, 17, and 14 transgenic lines from $100 \mathrm{mg}$ FEC (approximately 20 FEC clusters) of Serere, Ebwanatereka and Kibandameno, respectively, whereas about 28 transgenic lines were produced from $100 \mathrm{mg}$ of FEC of cultivar 60444. However, Bull et al. (2009) reported production of 50 transgenic lines from 100 FEC clusters of cultivar 60444 and slightly lower efficiencies for TME accessions were reported (Zainuddin et al., 2012). Chetty et al. (2013) reported 45 transgenic lines from 140 FEC clusters of cultivar T200. Taylor et al. (2012) obtained 14-28 transgenic lines per $\mathrm{cm}^{3}$ of settled cell volume of FECs of 60444. Comparing transformation efficiencies in cassava is complicated because of differences in genotypes, tissue culture system, transformation methods and even differences in regeneration capacity among FEC lines derived from the same genotype. Therefore, variability of transformation efficiencies between independent procedures cannot be eliminated. This study has shown successful transformation system for cultivars Serere, Ebwanatereka and Kibandameno, for which transformation had not previously been reported. Although, Taylor et al. (2012) reported a platform for production of transgenic cassava, but it was only reported for the model cultivar 60444 and not tested for any of the farmer-preferred cultivars.

The most commonly used histochemical analysis in plant genetic engineering programmes is the gusA visual marker gene (Jefferson, 1987). This is an invaluable tool for developing genetic engineering technologies in new cultivars and as a tool for teaching and training in the basic aspects of this technology. In this study, transient GUS expression assay after 3 days of co-cultivation showed blue coloration confirming transient expression of the reporter gene in FECs of all the four cultivars (Figures 3A,B). However, variations in the frequency of blue foci were observed among the four cultivars tested (Table 3 ). The percentage of GUS positive calli ranged from 46 to $61 \%$ (Table 4). Cultivar 60444 yielded higher frequencies of transient GUS

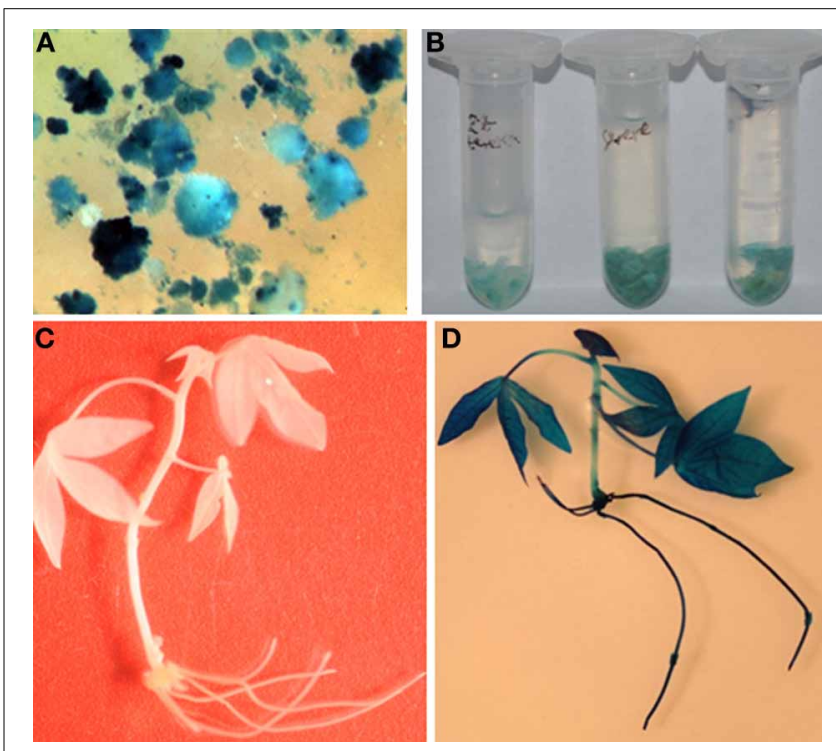

FIGURE 3 | Transient and stable expression of GUS in co-cultivated calli and hygromycin-resistant transformants. (A) transient GUS expression after 3 days of co-cultivation; (B) stable GUS expression in somatic embryos of Ebwanatereka (left), Serere (middle) and cultivar 60444 (right); (C) no GUS expression in non-transgenic control plant; (D) stable expression of the GUS gene in transgenic Serere plantlet.

expression. The hygromycin-resistant calli and mature somatic embryos stained a uniform blue color (Figures 1E and G). GUS assay confirmed the transgenic nature of regenerated plantlets (Figure 1I). A uniform blue coloration was observed in regenerated transgenic plants, confirming stable expression of gusA gene throughout the plant whereas no blue coloration was observed in non-transgenic plants (Figures 3C,D).

A $215 \mathrm{bp}$ amplicon corresponding to the internal fragment of gusA gene was amplified from genomic DNA of all selected transgenic plants using gusA gene-specific primers (Figure 4A), confirming the presence of gus A transgene in transgenic plants. A $415 \mathrm{bp}$ amplicon was observed in all selected transgenic plants using $h p t$-specific primers (Figure 4B), confirming the presence of both gusA and $h p t$ genes. Southern blot analysis was performed with HindIII-digested genomic DNA in order to confirm the transgene integration and determine the number of inserted copies. Bands corresponding to transgene integration were observed for the selected transgenic plants confirming gene 


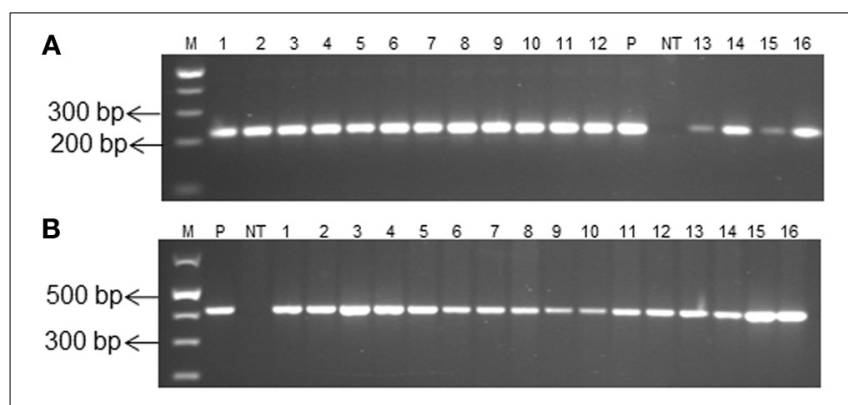

FIGURE 4 | PCR analysis of transgenic cassava lines using (A) gusA (B) hpt-specific primers. Lanes: $\mathrm{M}$, molecular size marker (1 kb plus DNA ladder); NT, non-transgenic plantlet DNA; P, pCAMBIA1301 plasmid DNA as a positive control; 1-8, 9-12, and 13-16, transformed cassava lines of cultivars 60444, Serere and Ebwanatereka, respectively.

integration in plant genome, whereas no band was observed for the non-transgenic control (Supplementary Figure 2). Several transgenic plants were acclimatized in coconut pit in plastic pots and transferred to soil in pots in the glasshouse. The plants exhibited identical morphology compared with control non-transgenic plants.

\section{GENETIC ENGINEERING OF TARGET TRAITS}

Efforts to improve cassava through genetic engineering have concentrated on a few major traits to complement conventional breeding. The major ones in Africa are resistance to viral and bacterial diseases and tolerance to PPD. Viral diseases are the most important biotic limitation to cassava production in sub-Saharan Africa, and particularly in east Africa, where CBSD and CMD combine to impact the crop (Legg et al., 2011). The development of virus-resistant locally adapted cultivars is restricted by limitations inherent to traditional breeding (Ceballos et al., 2004). In the last two decades, RNAi-based approaches were tested in transgenic cassava and proved to confer robust CMD resistance in the model cassava cultivar 60444 (Vanderschuren et al., 2007, 2009). However, stability of the engineered CMD resistance remains to be demonstrated under field conditions and over multiple cycles of propagation (Donald Danforth Plant Science Center, 2006).

CBSD has recently emerged as an important threat to cassava production in east Africa (Alicai et al., 2007). Because farmerpreferred landraces and newly-bred cassava cultivars deployed in east Africa lack CBSD resistance, genetic engineering has been considered as a promising approach to rapidly implement CBSD resistance in cultivars currently preferred by farmers in east Africa. Laboratories in USA and Europe have demonstrated that CBSD resistance can be engineered in cassava using an RNAibased approach targeting the coat protein sequence of CBSVs (Yadav et al., 2011; Ogwok et al., 2012; Vanderschuren et al., 2012). These results showed that RNAi approach is a promising technology for engineering CBSD resistance in east African farmer-preferred landraces to reduce the increasing impact of cassava viral diseases.

Cassava production can also be severely affected by cassava bacterial blight (CBB), caused by gram-negative bacteria
Xanthomonas axonopodis pv. manihotis (Xam). This disease is present in all regions where cassava is grown and production losses can reach up to 80 or 100\% (Verdier et al., 2004; Ogunjobi and Dixon, 2006). While there are a few cassava cultivars that show relatively high levels of natural resistance to CBB (Restrepo et al., 2004), they are either not well adapted to particular agroecological regions where cassava is cultivated or do not exhibit the farmer- and/or consumer-preferred characteristics. To our knowledge, transgenic methods to improve resistance to CBB have not been reported yet. Therefore, the knowledge of plant immunity on model plants and other crops, such as Arabidopsis and rice, could be brought to cassava. The introduction of PRR genes, such as the Xa21 from rice or EFR (Elongation Factor Receptor) in cassava, could provide a broad and durable resistance to $\mathrm{CBB}$, as has been demonstrated for other plants (Lacombe et al., 2010; Mendes et al., 2010). Genetically engineered resistance against bacteria has also been achieved in banana by using genes regulating programmed cell death such as hypersensitive response-assisting protein (Hrap) and plant ferredoxin-like protein (Pflp) from sweet pepper (Capsicum annuum) (Tripathi et al., 2010; Namukwaya et al., 2012). Such an approach could also be used to enhance resistance of cassava against bacterial blight in the near future.

Although cassava yield is high, and its storage root is rich in starch, the PPD of cassava roots seriously affects its storage and utilization (Wheatley et al., 1985). Development of cassava varieties with improved storage performance would benefit farmers, consumers and industries. The total benefits for cassava varieties including delayed PPD were estimated to be in the range of $\$ 280$ million for Uganda only (Rudi et al., 2010). As a unique biological phenomenon, PPD in cassava is a physiological and biochemical decay process caused by an oxidative burst in storage root cells. PPD has a close relationship with reactive oxygen species (ROS) (Reilly et al., 2004). With the increased study of the temporal and spatial expressions of genes related to ROS production and scavenging in the process of cassava PPD (Reilly et al., 2007; Owiti et al., 2011), as well as the functional verification of these key genes, it is possible to interfere with the PPD process through the regulation of ROS-scavenging activities. The alteration of key enzymes or factors in the PPD pathway might effectively reduce the occurrence of PPD in farmer-preferred cultivars as recently demonstrated in the model cultivar 60444 (Zidenga et al., 2012; Xu et al., 2013).

\section{CONCLUSION}

Successful application of transgenic technologies in cassava will depend not only on technical advances, but also on successful transfer of knowledge, tools and expertise to the countries in which cassava has an important socioeconomic role. The establishment of cassava transformation platform(s) in institutions in Africa will promote research capabilities and allow scientists autonomy to adapt cassava to suit local agro-ecosystems, ultimately serving to develop a sustainable biotechnology infrastructure in African countries.

To our knowledge this is the first report on successful Agrobacterium-mediated transformation of African farmerpreferred cassava cultivars in a laboratory based in sub-Saharan 
Africa. It is a result of collaborative process involving IITA, Nairobi and ETH, Zurich. The scientific approach followed in this report will serve as model to implement genetic transformation of other cassava cultivars that are agronomically important in Africa. In sub-Saharan Africa, capacities for the production of transgenic crop plants have only recently been developed and remain limited to few crops like banana and maize (Tripathi et al., 2010, 2012; Namukwaya et al., 2012; Ombori et al., 2013). We consider that the present report represents an important step toward building a capacity for transgenic technologies in subSaharan Africa. This transformation platform will also acts as an important beginning for the use of transgenic technologies to address cassava production constraints in Africa such as viral and bacterial disease resistance, prolonged shelf life and nutritional enhancement.

In conclusion, a platform for the high throughput production of transgenic cassava has been developed in farmer-preferred cultivars in east Africa at IITA which will serve as a potential platform for training NARS in sub-Saharan Africa for developing improved cassava varieties with important traits like disease resistance.

\section{ACKNOWLEDGMENTS}

The authors would like to thank IITA and United States Agency for International Development (USAID) for financial support of this work and the Biosciences eastern and central Africa (BecA)-International Livestock Research Institute, Kenya for providing the laboratory facilities. Evans Nyaboga trained two years at ETH Zurich on the cassava genetic transformation platform under the BioCassavaPlus (Phase 1) trainee programme. Evans Nyaboga and Joshua Njiru received Ph.D. fellowship from IITA and USAID, respectively. We also thank Dr. Nigel Taylor (Donald Danforth Plant Science Center) for valuable discussion and suggestions on the cassava transformation protocol.

\section{SUPPLEMENTARY MATERIAL}

The Supplementary Material for this article can be found online at: http://www.frontiersin.org/journal/10.3389/ fpls.2013.00526/abstract

Table S1 | Composition of media used in tissue culture and transformation experiments.

Figure S1 | Schematic representation of gene construct used for cassava transformation. The T-DNA region of construct pCAMBIA1301 with gusA and $h p t$ genes. LB/RB, left/right T-DNA border sequences; CAMV35SP, CaMV 35S promoter; hpt, coding region of the hygromycin $\mathrm{B}$ resistance gene; nptll, coding region of the neomycin resistance gene; NOS, nopaline synthase; intron-gusA, $\beta$-glucuronidase containing intron. Arrows indicate direction of transcription.

Figure S2 | Southern blot analyses of genomic DNA of transgenic lines restricted with HindIII using PCR-amplified product of gus $\boldsymbol{A}$ gene as a probe. M, DIG-labeled DNA marker; NT, non-transgenic plant; lanes 5, 20 and 22 are transgenic lines of cultivar $60444 ; 9,10$, and 12 are transgenic lines of cultivar Serere; 18 and 19 are, transgenic lines of cultivar Ebwanatereka.

\section{REFERENCES}

Alicai, T., Omongo, C. A., Maruthi, M. N., Hillocks, R. J., Baguma, Y., Kawuki, R., et al. (2007). Re-emergence of cassava brown streak disease in Uganda. Plant Dis. 91, 24-29. doi: 10.1094/PD-91-0024

Baba, A. I., Nogueira, F. C. S., Pinheiro, C. B., Brasil, J. N., Jereissati, E. S., Jucá, T. L., et al. (2008). Proteome analysis of secondary somatic embryogenesis in cassava (Manihot esculenta). Plant Sci. 175, 717-723. doi: 10.1016/j.plantsci. 2008.07.014

Barampuram, S., and Zhang, Z. J. (2011). Recent advances in plant transformation. Methods Mol. Biol. 701, 1-35. doi: 10.1007/978-1-61737-957-4_1

Bull, S. E., Owiti, J. A., Niklaus, M., Beeching, J. R., Gruissem, W., and Vanderschuren, H. (2009). Agrobacterium-mediated transformation of friable embryogenic calli and regeneration of transgenic cassava. Nat. Protoc. 4, 1845-1854. doi: 10.1038/nprot.2009.208

Ceballos, H., Iglesias, C. A., Perez, J. C., and Dixon, A. G. O. (2004). Cassava breeding: opportunities and challenges. Plant Mol. Biol. 56, 503-516. doi: 10.1007/s11103-004-5010-5

Chetty, C. C., Rossin, C. B., Gruissem, W., Vanderschuren, H., and Rey, M. E. C. (2013). Empowering biotechnology in southern Africa: establishment of a robust transformation platform for the production of transgenic industrypreferred cassava. New Biotechnol. 30, 136-143. doi: 10.1016/j.nbt.2012.04.006

Donald Danforth Plant Science Center. (2006). News Release (Danforth Center Cassava Update, Friday May 26th, 2006). Available online at: www.danforth center.org/wordpress/?page_id=395\&pid=1474 (Accessed November 10, 2012).

Ezezika, O. C., Daar, A. S., Barber, K., Mabeya, J., Thomas, F., Deadman, J., et al. (2012). Factors influencing agbiotech adoption and development in sub-Saharan Africa. Nat. Biotechnol. 30, 193. doi: 10.1038/nbt0212-193a

FAOSTAT. (2008). FAOSTAT statistical database, agriculture data. Available online at: http://apps.fao.org

FAOSTAT. (2012). FAOSTAT statistical database, agriculture data. Available online at: http://apps.fao.org

Fregene, M., and Puonti-Kaerlas, J. (2002). "Cassava biotechnology" in Cassava: Biology, Production and Utilization, eds R. J. Hillocks, J. M. Thresh, and A. C. Bellotti (Wallingford: CAB International), 179-207. doi: 10.1079/9780851995243.0179

Gelvin, S. B. (2003). Agrobacterium-mediated plant transformation: the biology behind the "gene jockeying" tool. Microbiol. Mol. Biol. Rev. 67, 16-37. doi: 10.1128/MMBR.67.1.16-37.2003

González, A. E., Schöpke, C., Taylor, N. J., Beachy, R. N., and Fauquet, C. M. (1998) Regeneration of transgenic cassava plants (Manihot esculenta Crantz) through Agrobacterium-mediated transformation of embryogenic suspension cultures. Plant Cell Rep. 17, 827-831. doi: 10.1007/s002990050492

Gresshoff, P., and Doy, C. (1974). Derivation of a haploid cell line from Vitis vinifera and the importance of the stage of meiotic development of anthers for haploid culture of this and other genera. Zeitschrift für Pflanzenphysiologie 73, 132-141. doi: 10.1016/S0044-328X(74)80084-X

Hankoua, B. B., Ng, S. Y. C., Puonti-Kaerlas, J., Fawole, I., Dixon, A. G. O., and Pillay, M. (2005). Regeneration of a wide range of African cassava genotypes via shoot organogenesis from cotyledon of maturing somatic embryos and conformity of the field-established regenerants. Plant Cell Tissue Organ Cult. 81, 200-211. doi: 10.1007/s11240-005-0514-5

Jansson, C., Westerbergh, A., Zhang, J., and Xinwen Hu, S. C. (2009). Cassava, a potential biofuel crop in (the) People's Republic of China. Appl. Energy 86, S95-S99. doi: 10.1016/j.apenergy.2009.05.011

Jefferson, R. A. (1987). Assaying chimeric genes in plants: the GUS gene fusion system. Plant Mol. Biol. Rep. 5, 387-405. doi: 10.1007/BF02667740

Kawuki, R. S., Pariyo, A., Amuge, T., Nuwamanya, E., Ssemakula, G., Tumwesigye, S., et al. (2011). A breeding scheme for local adoption of cassava (Manihot esculenta Crantz). J. Plant Breed. Crop Sci. 3, 120-130.

Koehorst-van Putten, H. J. J., Sudarmonowati, E., Herman, M., Pereira-Bertram, I. J., Wolters, A. M. A., Meima, H., et al. (2012). Field testing and exploitation of genetically modified cassava with low-amylose or amylosefree starch in Indonesia. Transgenic Res. 21, 39-50. doi: 10.1007/s11248-0119507-9

Lacombe, S., Rougon-Cardoso, A., Sherwood, E., Peeters, N., Dahlbeck, D., van Esse, H. P., et al. (2010). Interfamily transfer of a plant pattern-recognition receptor confers broad-spectrum bacterial resistance. Nat. Biotechnol. 28, 365-369. doi: 10.1038/nbt.1613 
Legg, J. P., Jeremiah, S. C., Obiero, H. M., Maruthi, M. N., Ndyetabula, I., OkaoOkuja, G., et al. (2011). Comparing the regional epidemiology of the cassava mosaic and cassava brown streak virus pandemics in Africa. Virus Res. 159, 161-170. doi: 10.1016/j.virusres.2011.04.018

Li, H. Q., Sautter, C., Potrykus, I., and Pounti-Kaerlas, J. (1996). Genetic transformation of cassava (Manihot esculenta Crantz). Nat. Biotechnol. 14, 736-740. doi: 10.1038/nbt0696-736

Liu, J., Zheng, Q., Ma, Q., Gadidasu, K. K., and Zhang, P. (2011). Cassava genetic transformation and its application in breeding. J. Integr. Plant Biol. 53, 552-569. doi: 10.1111/j.1744-7909.2011.01048.x

Machuka, J. (2001). Agricultural Biotechnology for Africa. African scientists and farmers must feed their own people. Plant Physiol. 126, 16-19. doi: 10.1104/pp.126.1.16

Mendes, B. M. J., Cardoso, S. C., Boscariol-Camargo, R. L., Cruz, R. B., Mourão Filho, F. A. A., and Bergamin Filho, A. (2010). Reduction in susceptibility to Xanthomonas axonopodis pv. citri in transgenic Citrus sinensis expressing the rice Xa21 gene. Plant Pathol. 59, 68-75. doi: 10.1111/j.1365-3059.2009.02148.x

Namukwaya, B., Tripathi, L., Tripathi, J. N.,Arinaitwe, G., Mukasa, S. B., and Tushemereirwe, W. K. (2012). Transgenic banana expressing Pflp gene confers enhanced resistance to Xanthomonas Wilt Disease. Transgenic Res. 12, 855-865. doi: 10.1007/s11248-011-9574-y

National Cassava Programme-Uganda Report. (2005). Integration of Gender, SocioEconomic and Market Factors for Expanded Cassava Production in the Teso and Lango Farming Systems. NARO/DFID CORF3029 Project Terminal Report.

Ntawuruhunga, P., and Legg, J. P. (2007). New Spread of Cassava Brown Streak Virus Disease and its Implications for the Movement of Cassava Germplasm in the East and Central African Region, 2007. 1-6. Available online at: http://c3project.iita. org/Doc/A25-CBSDbriefMay26.pdf

Ogunjobi, A. A., and Dixon, A. (2006). Molecular variation in population structure of Xanthomonas axonopodis pv. manihotis in the southeastern Nigeria. Afr. J. Biotechnol. 5, 1868-1872.

Ogwok, E., Odipio, J., Halsey, M., Gaitan-Solis, E., Bua, A., Taylor, N., et al. (2012). Transgenic RNA interference (RNAi)-derived field resistance to cassava brown streak disease. Mol. Plant Pathol. 13, 1019-1031. doi: 10.1111/j.13643703.2012.00812.x

Ombori, O., Muoma, J. V. O., and Machuka, J. (2013). Agrobacterium-mediated genetic transformation of selected tropical inbred and hybrid maize (Zea mays L.) lines. Plant Cell, Tissue Organ Cult. 113, 11-23. doi: 10.1007/s11240-0120247-1

Owiti, J., Grossmann, J., Gehrig, P., Dessimoz, C., Laloi, C., Hansen, M. B., Gruissem, W., and Vanderschuren, H. (2011). iTRAQ-based analysis of changes in the cassava root proteome reveals pathways associated with postharvest physiological deterioration. Plant J. 67, 145-156. doi: 10.1111/j.1365313X.2011.04582.x

Raemakers, C. J. J. M., Schreuder, M., Pereira, I., Munyikwa, T., Jacobsen, E., and Visser, R. G. F. (2001). Progress made in FEC transformation of cassava. Euphytica 120, 15-24. doi: 10.1023/A:1017574713880

Reilly, K., Bernal, D., Cortes, D. F., Gomez-Vasquez, R., Tohme, J., and Beeching, J. R. (2007). Towards identifying the full set of genes expressed during cassava post-harvest physiological deterioration. Plant Mol. Biol. 64, 187-203. doi: 10.1007/s11103-007-9144-0

Reilly, K., Buschmann, R., Tohme, J., and Beeching, J. R. (2004). Oxidative stress responses during post-harvest physiological deterioration. Plant Mol. Biol. 56, 625-641. doi: 10.1007/s11103-005-2271-6

Restrepo, S., Velez, C. M., Duque, M. C., Verdier, V. (2004). Genetic structure and population dynamics of Xanthomonas axonopodis pv. Manihotis in Colombia from 1995 to 1999. Appl. Environ. Microbiol. 70, 255-261. doi: 10.1128/AEM.70.1.255-261.2004

Rudi, N., Norton, G. W., Alwang, J., and Asumugha, G. (2010). Economic impact analysis of marker-assisted breeding for resistance to pests and postharvest deterioration in cassava. Afr. J. Agric. Resour. Econ. 4, 110-122.

Sayre, R., Beeching, J., Cahoon, E., Egesi, C., Fauquet, C., Fellman, J., et al. (2011). The BioCassava Plus Program: biofortification of cassava for sub-Saharan Africa. Annu. Rev. Plant Biol. 62, 251-272. doi: 10.1146/annurev-arplant042110-103751

Schöpke, C., Taylor, N. J., Carcamo, R., Konan, N. K. K., Marmey, P., Henshaw, G. G., et al. (1996). Regeneration of transgenic cassava plants (Manihot esculenta Crantz) from microbombarded embryogenic suspension cultures. Nat. Biotechnol. 14, 731-735. doi: 10.1038/nbt0696-731
Shibata, D. and Liu, Y. G. (2000). Agrobacterium-mediated plant transformation with large DNA fragments. Trends Plant Sci. 5, 354-357. doi: 10.1016/S13601385(00)01689-7

Soni, R., and Murray, J. A. (1994). Isolation of intact DNA and RNA from plant tissues. Anal. Biochem. 218, 474-476. doi: 10.1006/abio.1994.1214

Taylor, N. J., Chavarriaga, P., Raemakers, K., Siritunga, D., and Zhang, P. (2004). Development and application of transgenic technologies in cassava. Plant Mol. Biol. 56, 671-688. doi: 10.1007/s11103-004-4872-x

Taylor, N. J., Kiernan, R. J., Henshaw, G. G., and Blakesley, D. (1997). Improved procedures for producing embryogenic tissues of African cassava genotypes: Implications for genetic transformation. Afr. J. Roots Tuber Crops 2, 200-204.

Taylor, N. J., Masona, M. V., Schopke, C., and Fauquet, C. M. (2002). "Transgenic cassava for food security and economic development," in Transgenic Plants and Crops, eds G. G. Khachatourians, A. McHughen, R. Scorza, W. K. Nip, and Y. H. Hui (New York, NY: CRC press), 523-546.

Taylor, T., Gaitán-Solís, E., Moll, T., Trauterman, B., Jones, T., Pranjal, A., et al. (2012). A High-throughput platform for the production and analysis of transgenic cassava (Manihot esculenta) plants. Trop. Plant Biol. 5, 127-139. doi: 10.1007/s12042-012-9099-4

Toennissen, G. H., Toole, J. C. O., and DeVries, J. (2003). Advances in plant biotechnology and its adoption in developing countries. Curr. Opin. Plant Biol. 6, 191-198. doi: 10.1016/S1369-5266(03)00002-5

Tripathi, J. N., Muwonge, A., and Tripathi, L. (2012). Efficient regeneration and transformation protocol for plantain cultivar 'Gonja Manjaya' (Musa spp. AAB) using embryogenic cell suspension. In vitro Cell Dev. Biol. Plant 48, 216-224. doi: $10.1007 /$ s11627-011-9422-z

Tripathi, L., Mwaka, H., Tripathi, J. N., and Tushemereirwe W. K. (2010). Expression of sweet pepper hrap gene in banana enhances resistance to Xanthomonas campestris pv. musacearum. Mol. Plant Pathol. 11, 721-731. doi: 10.1111/j.1364-3703.2010.00639.x

Vanderschuren, H. (2012). Strengthening African R\&D through effective transfer of tropical crop biotech to African Institutions. Nat. Biotechnol. 30, 3-4. doi: $10.1038 /$ nbt. 2405

Vanderschuren, H., Alder, A., Zhang, P., and Gruissem, W. (2009). Dosedependent RNAi-mediated geminivirus resistance in the tropical root crop cassava. Plant Mol. Biol. 70, 265-272. doi: 10.1007/s11103009-9472-3

Vanderschuren, H., Moreno, I., Anjanappa, R. B., Zainuddin, I. M., and Gruissem, W. (2012). Exploiting the combination of natural and genetically engineered resistance to cassava mosaic and cassava brown streak viruses impacting cassava production in Africa. PLoS ONE 7:e45277. doi: 10.1371/journal.pone. 0045277

Vanderschuren, H., Stupak, M., Futterer, J., Gruissem, W., and Zhang, P. (2007). Engineering resistance to geminiviruses-review and perspectives. Plant Biotechnol. J. 5, 207-220. doi: 10.1111/j.1467-7652.2006.00217.x

Verdier, V., Restrepo, S., Mosquera, G., Jorge, V., and Lopez, C. (2004). Recent progress in the characterization of molecular determinants in the Xanthomonas axonopodis pv. manihotis-cassava interaction. Plant Mol. Biol. 56, 573-584. doi: 10.1007/s11103-004-5044-8

Wheatley, C., Lozano, C. and Gomez, G. (1985). "Post-harvest deterioration of cassava roots," in Cassava: Research, Production and Utilization, eds J. H. Cock and J. A. Reyes. (Cali: UNDP-CIAT), 655-671.

Xu, J., Duan, X., Yang, J., Beeching, J. R., and Zhang, P. (2013). Enhanced reactive oxygen species scavenging by overproduction of superoxide dismutase and catalase delays postharvest physiological deterioration of cassava storage roots. Plant Physiol. 161, 1517-1528. doi: 10.1104/pp. 112.212803

Yadav, J. S., Ogwok, E., Wagaba, H., Patil, B. L., Bagewadi, B., Alicai, T., et al. (2011) RNAi-mediated resistance to cassava brown streak Uganda virus in transgenic cassava. Mol. Plant Pathol. 12, 677-687. doi: 10.1111/j.1364-3703.2010. 00700.x

Zainuddin, I., Schlegel, K., Gruissem, W., and Vanderschuren, H. (2012). Robust transformation procedure for the production of transgenic farmerpreferred cassava cultivars. Plant Methods 8, 24. doi: 10.1186/17464811-8-24

Zhang, P., Vanderschuren, H., Futterer, J., and Gruissem, W. (2005). Resistance to cassava mosaic disease in transgenic cassava expressing antisense RNAs targeting virus replication genes. Plant Biotechnol. J. 3, 385-399. doi: 10.1111/j.14677652.2005.00132.x 
Zhang, P., Wang, W. Q., Zhang, G. L., Kaminek, M., Dobrev, P., Xu, J., and Gruissem, W. (2010). Senescence-inducible expression of isopentenyl transferase extends leaf life, increases drought stress resistance and alters cytokinin metabolism in cassava. J. Integr. Plant Biol. 52, 653-669. doi: 10.1111/j.17447909.2010.00956.x

Zidenga, T., Leyva-Guerrero, E., Moon, H., Siritunga, D., and Sayre, R. (2012). Extending cassava root shelf life via reduction of reactive oxygen species production. Plant Physiol. 154, 1396-1407. doi: 10.1104/pp.112. 200345

Conflict of Interest Statement: The authors declare that the research was conducted in the absence of any commercial or financial relationships that could be construed as a potential conflict of interest.
Received: 15 October 2013; accepted: 06 December 2013; published online: 24 December 2013.

Citation: Nyaboga E, Njiru J, Nguu E, Gruissem W, Vanderschuren H and Tripathi $L$ (2013) Unlocking the potential of tropical root crop biotechnology in east Africa by establishing a genetic transformation platform for local farmer-preferred cassava cultivars. Front. Plant Sci. 4:526. doi: 10.3389/fpls.2013.00526

This article was submitted to Plant Biotechnology, a section of the journal Frontiers in Plant Science.

Copyright (๑) 2013 Nyaboga, Njiru, Nguu, Gruissem, Vanderschuren and Tripathi. This is an open-access article distributed under the terms of the Creative Commons Attribution License (CC BY). The use, distribution or reproduction in other forums is permitted, provided the original author(s) or licensor are credited and that the original publication in this journal is cited, in accordance with accepted academic practice. No use, distribution or reproduction is permitted which does not comply with these terms. 